American Journal of Economics and Business Administration 1 (4): 270-277, 2009

ISSN 1945-5488

(C) 2009 Science Publications

\title{
Multilareral Environment Agreements Versus the World Trade Organization System
}

\author{
Sushant Chandra and Aviral Dhirendra \\ Gujarat National Law University, Gandhinagar, India
}

\begin{abstract}
Problem statement: Since the inception of WTO in 1994, the protection of environment has evolved as a key issue due to recurrent trade transaction occurring among the states. WTO constituted a committee on Trade and Environment in 1995 to evaluate the scope of complementarities between trade liberalization and environmental protection. However Doha Development Agenda of 2001 and Article XX of GATT have proven to be a beacon light in such an evaluation but still it is observed that various states have resorted to varied margin of appreciation in applying restrictions. Thus this article bewrays the varied practices adopted by the states in this regards. Approach: Determining the approach of the states in striking a balance between the transnational trade practices and protecting environment from depletion caused by such practices. Also to determine an efficacious method for dealing the existing menace. The research methodology resorted to in the completion of this article is doctrinal in nature. The sources escorted belong to the genre of both external and internal. Omnibus of articles, books and electronic resources have been referred to for completing the article. The method of writing is primarily descriptive. The official website of WTO has proven to be of tremendous help. A uniform mode of citation has been followed throughout the article. Result: There are myriad of multilateral environmental agreements which usually incorporate environmental norms that may result in clashes with trade norms of the WTO. Reconciliation can only be possible with good faith negotiations under the Doha Development Agenda with renewed vigour and full commitments from both trade and environment advocates. Conclusion: In the event of any future conflict between the WTO rules and MEAs, trade advocates cannot simply argue that the WTO Agreements take priority and thus prevail over any other conflicting international treaties because the environmental side has the ability to argue the same. Thus the best way to avoid such a situation is to include a 'conflict clause' or at least to contain cross references in both types of Agreements.
\end{abstract}

Key words: WTO, multilateral environment agreements, shrimp turtle case, the chapeau, conflict clause

\section{INTRODUCTION}

The first attempt to govern international trade resulted in the General Agreement on Tariffs and Trade (GATT) in 1947 (briefly discussed under heading the history and the environment from GATT to the WTO). Environmental issues had not yet emerged in the international context and environmental organizations such as Greenpeace did not exist in developed countries at that time ${ }^{[3]}$. Environmental issues slowly started to penetrate domestic and international policy during the mid-1970s (Id). In 1991, the GATT contracting parties convened the Working Group on Environmental Measures, which formally established environmental issues within the multilateral trading system (Id). The emphasis on the environment continued at Marrakesh with the formation of the World Trade Organization's (WTO) Committee on Trade and the Environment (CTE) (discussed briefly under Heading THE multilateral trading system acknowledges environmental issues). However, environmental concerns sometimes conflict with the goals of multilateral trade and these discrepancies have created a dispute regarding the relevance and importance of incorporating environmental issues into modern trade negotiations. MEAs began gaining support with the environmental movement in the 1970s as a means of addressing the global impact of localized environmental degradation. MEAs are essentially treaties between States with the purpose of protecting the global environment. MEAs accomplish their purpose through various tools, such as requiring prior notification of 
potential environmentally threatening practices, prohibiting the production and trade of environmentally damaging products, introducing compliance assistance mechanisms and a myriad of other trade-related and non-trade provisions, some of which codify existing international norms ${ }^{[8]}$.

The history of trade and the environment from GATT to the WTO:

The UN, the ITO and the birth of GATT: Environmental concerns held a low priority in the early years of international trade. The daunting task of alleviating the extensive devastation to economic and domestic infrastructures across Europe and Southeast Asia brought about dramatic social, economic and political changes throughout the world and overshadowed environmental concerns ${ }^{[4]}$. The dilemma of conducting trade efficiently in the post war economy was discussed at Bretton Woods in 1944 and sparked an effort to found an international organization charged with the development and coordination of international trade (Id., at 1-9). Fifty-one States concerned with post war political and economic instability formed the United Nations (UN) in 1945. The UN adopted a resolution in 1946 to undertake the formation of the International Trade Organization (ITO) (Id. The ITO ultimately floundered because the United States failed to lend its support, which would have ensured adoption by the remaining major trading nations). The original twenty-two states that wanted to adopt the tariff schedules of the GATT signed the "Protocol of Provisional Application" to apply the GATT ${ }^{[5]}$. The agreement became effective on January 1, 1948 (Id). Although it was only intended to be a temporary solution, the GATT became the default instrument for international trade negotiations and regulation for over 40 years. The drafters of the GATT never intended it to serve as an international organization and consequently it suffers from inherent weaknesses, including the lack of any legal identity or organizational structure. These failings led to ambiguity about the GATT's authority and ability to regulate trade (Id). Despite the aforementioned flaws, the GATT remained the dominant forum for trade negotiations and fostered eight "rounds" of multilateral trade discussions, which lowered tariffs and eliminated other international trade barriers.

The Uruguay round and the formation of the WTO: The birth, function and structure of the WTO: A basic understanding of the principles upon which the WTO was founded is essential to analyzing the impact of environmental issues on the multilateral trading regime. Globalization of the world economy facilitated the need for a stronger international body to not only advance but also govern international trade (Id. at 1-3). The contracting parties of the GATT undertook the Uruguay Round, a series of meetings, which lasted from 1986-1994, negotiating several agreements signed on April 15, 1994. The summits culminated in the formation of the World Trade Organization on January 1, 1995 (Id).

The WTO's objectives include: (1) facilitating, implementing and administering WTO agreements, the Multilateral Trade Agreements and the Plurality Trade Agreements; (2) providing a forum for trade negotiation; (3) administering the Dispute Settlement Understanding; (4) administering the Trade Policy Review Mechanism and (5) cooperating with the World Bank, International Monetary Fund and other international organizations. Unlike the GATT, the WTO possesses legal personality (Id. at 1147) and a much more powerful dispute resolution system with which to accomplish its objectives ${ }^{[6]}$. The WTO is organized in a hierarchy of conferences and councils. The Ministerial Conference, composed of all WTO members, is the upper echelon and must meet at least once every 2 years The General Council is also composed of all members and meets between Ministerial Conference sessions to conduct any pressing administrative functions (Id at 1147). Furthermore, the General Council discharges the duties of the Trade Review Policy Body and also acts as the Dispute Settlement Body, which is composed of both the dispute settlement panel and the Appellate Body (Id. at 1145).

The multilateral trading system acknowledges environmental issues:

Establishing the committee on trade and the environment: WTO members are deeply divided over whether to incorporate environmental issues into the multilateral trading system. Environmentalists claim that without environmental safeguards, trade will generate rampant growth causing unsustainable natural resource consumption and waste production. They are also concerned that without environmental protections built into the multilateral trading scheme, trade liberalization and market access agreements might trump environmental policy (Id). The Committee on Trade and Environment (CTE) was established under the WTO with the mandate to investigate the relationship between environmental and trade policies (The 1994 Ministerial Decision on Trade and Environment created the Committee on Trade and Environment (CTE), which is open to the entire WTO 
membership, with some international organizations as observers. The committee's mandate is broad and it has contributed to identifying and understanding the relationship between trade and the environment in order to promote sustainable development). Formation of the CTE 'was a reaction by GATT contracting parties to the controversy caused by the tuna-dolphin dispute. Which had caused NGOs to consider the GATT antienvironment and developing countries to worry that environmental norms were being used to restrict $\operatorname{trade}^{[7]}$. After the tuna-dolphin dispute, states made an attempt to reconcile trade and environmental concerns at the 1992 Rio Conference on Environment and Development (UNCED). The Rio Summit adopted Agenda 21, a major nonbinding policy document, the implementation of which is overseen by the UN Commission on Sustainable Development. Principle 12 of the Rio Declaration advances three key elements:

- Environmental measures dealing with transboundary or global problems should be based on international agreements

- Unilateral action to deal with such problems should be avoided and

- Environmental measures should not be arbitrarily or unjustifiably discriminatory or a disguised restriction on trade (Rio Declaration on Environment and Development, A/CONF.151/26 (Vol. 1), 12 August 1992. Principle 12 of the Rio Declaration reads: "States should cooperate to promote a supportive and open international economic system that would lead to economic growth and sustainable development in all countries, to better address the problems of environmental degradation. Trade policy measures for environmental purposes should not constitute a means of arbitrary or unjustifiable discrimination or a disguised restriction on international trade. Unilateral actions to deal with environmental challenges outside the jurisdiction of the importing country should be avoided. Environmental measures addressing transboundary or global environmental problems should, as far as possible, be based on an international consensus)

The CTE has taken Principle 12 as an operational guideline. It also follows the policy guideline of the Preamble to the Agreement establishing the World Trade Organization, which "allows for the optimal use of the world's resources in accordance with the objective of sustainable development, seeking both to protect and preserve the environment and to enhance the means for doing so in a manner consistent with their respective needs and concerns at different levels of economic development ${ }^{[9]}$. In accordance with the Work Program of the Doha Ministerial Declaration, negotiations have been made on the relationship between existing WTO rules and specific trade obligations set out in Multilateral Environmental Agreements (MEAs) (Id, art. 31. These negotiations focus on how WTO rules are to apply to WTO members that are parties to environmental agreements, in particular to clarify the relationship between certain trade measures taken under the environmental agreements and WTO rules). The Ministers in accordance with the Work Program of the Doha set points of reference or limitations, which were intended to preserve the integrity of the WTO system by preventing the CTE from addressing issues unrelated to trade (Id. at 1268). The Ministers quoted the Trade Negations Committee's (TNC) Decision of December 15, 1993, which established the following guidelines and objectives for the CTE:

- To identify the relationship between trade measures and environmental measures, in order to promote sustainable development

- To make appropriate recommendations on whether any modifications of the provisions of the multilateral trading system are required, compatible with the open, equitable and nondiscriminatory nature of the system, as regards, in particular:

- The need for rules to enhance positive interaction between trade and environmental measures, for the promotion of sustainable development, with special consideration to the needs of developing countries, in particular those of the least developed among them

- The avoidance of protectionist trade measures and the adherence to effective multilateral disciplines to ensure responsiveness of the multilateral trading system to environmental objectives set forth in Agenda 21 and the Rio Declaration, in particular Principle 12

- Surveillance of trade measures used for environmental purposes, of trade-related aspects of environmental measures which have significant trade effects and of effective implementation of the multilateral disciplines governing those measures

Basic obligations under the WTO rules and environmental exceptions:

Non-discrimination: Non-discrimination is the main principle on which the rules of the multilateral trading 
system are founded. It ensures that national environmental protection policies cannot arbitrarily discriminate between foreign and domestically made products, or between products imported from different trading partners. Non-discrimination has two components in the WTO.

Most-Favoured-Nation treatment (MFN): The MFN treatment is the cornerstone for achieving the objective of non-discrimination in international trade. Under the WTO Agreements, countries cannot normally discriminate between their trading partners. If a country grants another a special favour (such as lowering of a trade barrier-tariffs or non-tariffs-or opening up of a market), that country has to do so for the same goods or services for all its trading partners. This principle is known as MFN treatment. It is so important that it is the first article of the GATT (Art I) (Article I of the GATT 1994 reads: Any advantage, favour, privilege or immunity granted by any contracting party to any product originating in or destined for any other country shall be accorded immediately and unconditionally to the like product originating in or destined for the territories of all other contracting parties), which governs trade in goods.

National treatment: The principle of national treatment can be viewed as a corollary to the MFN treatment. According to this principle, imported and locally-produced goods should be treated equally - at least after the foreign goods have entered the market. The same should apply to foreign and domestic services and to foreign and local trademarks, copyrights and patents. This principle of national treatment is also found in all the three main WTO Agreements (GATS art XVII and TRIPS art 3). Article III (The products of the territory of any contracting party imported into the territory of any other contracting party shall be accorded treatment no less favourable than that accorded to like products of national origin in respect of all laws, regulations and requirements affecting their internal sale, offering for sale, purchase, transportation, distribution or use) and Article XI of GATT talks about Elimination of Quantitative Restrictions (No prohibitions or restrictions other than duties, taxes or other charges, whether made effective through quotas, import or export licences or other measures, shall be instituted or maintained by any contracting party on the importation of any product of the territory of any other contracting party or on the exportation or sale for export of any product destined for the territory of any other contracting party.18 The Article addresses the elimination of quantitative restrictions through quotas, import or export licenses, or other measures, introduced or maintained by countries on the importation or exportation of products. The main purpose of prohibiting such restrictions is to encourage countries to convert them into tariffs, which are more transparent and less likely to distort trade. This Article has been violated in the context of a number of environmentalrelated disputes in which countries have imposed bans on the importation of certain products and is thus subject to action that can be taken under the WTO rules) and Article XX: General Exceptions The "General Exceptions" provision of the GATT, Article $\mathrm{XX}$, constitutes conditional exceptions to GATT obligations, even those in Articles I, III and XI. Although the word "environment" is not used, Article XX may be applied to justify environmentally inspired rules that collide with trade (Subject to the requirement that such measures are not applied in a manner which would constitute a means of arbitrary or unjustifiable discrimination between countries where the same conditions prevail, or a disguised restriction on international trade, nothing in this Agreement shall be construed to prevent the adoption or enforcement by any contracting party of measures (b) necessary to protect human, animal or plant life or health $(\mathrm{g})$ relating to the conservation of exhaustible natural resources if such measures are made effective in conjunction with restrictions on domestic production or consumption). Paragraphs (b) and (g) are designed to allow WTO members to adopt policy measures that would normally be inconsistent with GATT, when "necessary" to protect human, animal or plant-life health, or if related to the conservation of exhaustible natural resources. The burden of showing that an Article XX exception applies lies on the party asserting it as a defence.

The chapeau: In the opening paragraph of Article XX there are exceptions what is commonly known as the "chapeau". Even if a measure meets the requirements of a provision of Article XX, it would be illegal if it constitutes (1): Arbitrary or unjustifiable discrimination between countries where the same conditions prevail; or (2): A disguised restriction on international trade.20. The anti-discrimination portion of the chapeau forbids both arbitrary and unjustifiable discrimination between "countries" without qualification; this prohibition appears to have the same field of application as GATT Articles I and III.

It would include all countries, both importing and exporting. However, in contrast to Articles I and III, it would mean, by implication, that Article XX allows discrimination between countries, as long as it is not arbitrary or unjustifiable. The best example of the 
application of the 'chapeau' is found in the US. Gasoline dispute (Discussed later under section Environmental Related Disputes Decided by the WTO).

Environmentally related disputes decided by the WTO: There has already been a series of environmentally-related disputes that have arisen within the framework of the $\mathrm{WTO}^{[10]}$. Six of these occurred under the GATT and five under the WTO itself. The "Tuna Dolphin" case ${ }^{[11]}$, which was decided by a GATT panel, will be commented on first to demonstrate the seriousness of the problem followed by an examination of the WTO's approach in respect of the environmentally-related disputes.

Tuna dolphin i case (Mexico against US) (decided by a GATT panel): Before 1991, the relationship between protection of the environment and international trade was a topic that attracted little attention. However, the situation totally changed with the decision of the Tuna Dolphin I case in which a GATT Panel declared a US embargo on tuna caught by fishing methods causing high dolphin mortality to be illegal. This case created an explosive academic debate and was the catalyst for an intense clash between trade specialists and environmentalists ${ }^{[1,2]}$. Acting under the US Marine Mammal Protection Act (MMPA), the United States had adopted a unilateral ban on imports of yellow-fin tuna using fishing methods that killed dolphins, a protected species under the MMPA. Upon Mexico's complaint to the GATT, a dispute settlement Panel found that the US tuna embargo violated GATT Article $\mathrm{XI}$ :1, which forbids measures prohibiting or restricting exports or imports. The United States sought to justify the embargo under GATT Article III:1 and III:4 because US fishermen were subject to the same MMPA rules. The GATT panel rejected the US argument on the ground that Article III: 1 and III:4 permit only regulations relating to products as such. As the MMPA regulations concerned harvesting techniques that could not possibly affect tuna as a product, the ban on tuna could not be justified. This holding was reiterated by a second GATT panel in the Tuna-Dolphin II decision, which involved the legality of a secondary embargo on tuna products from countries that processed tuna caught by the offending countries. The Tuna Dolphin II panel condemned the unilateral boycott in even stronger terms. These two GATT panel decisions represent the first tentative steps of the multilateral trading system to reconcile with the protection of the environment. Neither decision was binding under the GATT because both were not adopted by the contracting parties (Even if they were adopted, they would have little force as precedents because their reasoning was partially inconsistent and the decisions of prior GATT or WTO panel are not binding on future panels). Much of the reasoning in the Tuna Dolphin cases has been effectively overruled later on.

Shrimp-Turtle case (India, Malaysia, Pakistan and Thailand against US): In 1995, after the WTO was launched and the world's trade dispute process was restructured, the appellate body of the WTO was asked again to look at a similar dispute, known as the "Shrimp-Turtle" case. In 1997, India, Malaysia, Pakistan and Thailand requested the establishment of a panel against the US concerning a ban on importation of shrimp and shrimp products from these complainants imposed by the US under Section 609 of US Public Law 101-102. The US Endangered Species Act of 1973 listed as the five species of sea turtle as endangered. The Act requires that US shrimp trawlers use "Turtle Excluder Devices" (TEDs) in their nets when fishing in areas where there is a significant likelihood of encountering sea turtles. Essentially the act requires that shrimp boats use TEDs at all times. The complainants alleged that the US import ban violated Articles I, XI and XIII of GATT 1994. The Panel found that the import ban on shrimp and shrimp products as applied by the United States is inconsistent with Article XI:1 of the GATT 1994 (Section 609 of US Public law deals with imports ruling that shrimp harvested with technology that may adversely affect sea turtles may not be imported into the United States) and could not be justified under GATT Article XX. On appeal, the Appellate Body reversed the Panel's decision that the US measure at issue is not justified under Article XX of the GATT 1994. Yet it concluded that the US measure, while qualifying for provisional justification under Article XX (g), fails to meet the requirements of the chapeau (Which limits the use of import prohibitions or restrictions) of Article XX. The US lost the case, not because it sought to protect the environment but because it discriminated between WTO members. It provided countries in the Western hemisphere mainly in the Caribbean technical and financial assistance and longer transition periods for their fishermen to start using turtle-excluder devices. It did not give the same advantages, however, to the four Asian countries that filed the complaint with the WTO. The Appellate Body concluded that it was legitimate in WTO disputes to refer to the international obligations member states agreed to under Multi-Lateral Environmental Agreements (MEAs); these, like the GATT, are valid and concurrent international legal instruments. According to the Appellate Body, it was acceptable to put environmental protection measures in place, so long 
as the United States treated all trading partners equally; the United States, could not offer technical assistance to some countries but not others. As a result, the United States was required by the GATT to address and rectify this issue. The 'Shrimp-Turtle' case is a clear indication of the fact that GATT Article XX(b) and (g) exceptions may be used to protect the environment, provided that the measures are not discriminatory in nature. The ruling was also an acknowledgment that the WTO Appellate Body respected international obligations assumed by the United States under the Convention on International Trade in Endangered Species (CITES) (In particular, the requirement that such measures are not applied in a manner which would constitute a means of arbitrary or unjustifiable discrimination between countries). The "Shrimp-Turtle" decision somewhat satisfied the environmentalists, because it found that the United States could invoke the exception even without being party to an MEA, so long as it acted in a nondiscriminatory fashion.

EC-Asbestos case (Canada against EC): In the ECAsbestos case both the Panel and the Appellate Body rejected Canada's challenge against a French import ban on asbestos and asbestos-containing products. This reinforced the view that the WTO Agreements support members' ability to protect human health and safety at a level they deem appropriate. Chrysotile asbestos is generally considered to be a highly toxic material, exposure to which poses significant risks to human health. However, due to certain qualities, it has been widely used in various industrial sectors. To control the health risks associated with asbestos, the French Government imposed a ban on the substance as well as on products that contained it. The European Community justified the prohibition on the grounds of human health protection. Being the second largest producer of asbestos world-wide, Canada contested this prohibition through the WTO claiming that the Decree violated GATT Articles III: 4 and XI. The European Community requested the panel to confirm that the Decree was either compatible with Article III: 4 or necessary to protect human health within the meaning of Article XX (b).

Despite finding a violation of Article III, the panel ruled in favour of the EC. Panel found that the EC ban constituted a violation since asbestos and asbestos substitutes had to be considered "like products" within the meaning of that Article. However, the Panel found that the French ban could be justified under Article XX (b). The measure could be regarded as one which was "necessary to protect animal, human, plant life or health" reference. It also met the conditions of the chapeau of Article XX. On appeal, the WTO Appellate Body upheld the panel's ruling in favour of the EC, while modifying its reasoning on some issues. This ruling is a clear indication that the WTO dispute settlement mechanism would uphold any measure by the member states to protect the environment so long as it does not constitute a means of arbitrary or unjustifiable discrimination or a disguised restriction on international trade.

US Gasoline case (Venezuela and Brazil against US): Venezuela and Brazil claimed that the US Gasoline Rule, established under the Clean Air Act Amendments of 1990, was inconsistent with GATT Article III and was not protected by GATT Article XX exceptions. The case arose because it was alleged that the United States applied stricter rules on the chemical characteristics of imported gasoline than it did for that which was domestically refined. The complainants argued that this was unfair because US gasoline did not have to meet the same standards it violated the national treatment principle and could not be justified as an exception to normal WTO rules. A WTO panel, upon examining the US Gasoline Rule, concluded that it was not consistent with Article III: 4 of the GATT and could not be justified by any of the Article XX exceptions. The Panel found that the Gasoline Rule was inconsistent with Article III because it discriminated against the gasoline imports and could not be justified under Article XX (b) (d) or (g). On appeal, the Appellate Body upheld the panel's conclusion. It modified the panel report on the interpretation of GATT Article XX (g). The Appellate Body found that the baseline establishment rules contained in the:

Gasoline Rule fell within the terms of Article XX (g), but failed to meet the requirements of the "chapeau" of Article XX. It concluded, however, that Article XX (g) was not applicable in this case

Biotech case (US, Canada and Argentina against EC): The complainants brought a case against European Communities, asserting that the moratorium applied by the EC from October 1998 on the approval of biotech products, restricted imports of agricultural and food products from their countries. On 29 September 2006, the panel reports were circulated to Members. The Panel found that the European Communities applied a general de facto moratorium on the approval of biotech products between June 1999 and August 2003. The Panel further found that, by applying this moratorium, the European Community 
acted inconsistently with its obligations under Annex C(1)(a), first clause and Article 8 of the WTO Agreement on the Application of Sanitary and Phytosanitary Measures (SPS Agreement) because the de facto moratorium led to undue delays in the completion of EC approval procedures. The Panel, however, ruled that the European Community had not acted inconsistently with obligations under other provisions raised by the complainants. At the Dispute Settlement Body (DSB) meeting on 19 December 2006, the EC announced its intention to implement the ruling of the Panel. However, due to the complexity and sensitivity of the issues involved, it requested a reasonable period of time for implementation. Furthermore, it decided not to appeal the Panel ruling. Nevertheless, several civil society and environmental groups have sharply criticized the EC's decision, voicing concerns that some of the panel's conclusions could undermine other bodies of international law. In particular, they have warned that the ruling could undermine the 'precautionary principle' 37 , because the panel concluded that it was not obliged to take other international treaties into account if not all parties to the dispute were also parties to these treaties.38 In fact, the Panel's ruling is correct as far as international treaties are concerned but what the Panel failed to recognize was the role of customary international law and that the precautionary principle is accepted by many international lawyers as reflecting a customary rule.

Retreaded Tyres case (EC against Brazil): On 17 November 2005, the European Community brought a case against Brazil on the imposition of measures that adversely affect exports of retreaded tyres from the EC to the Brazilian market. Brazil had justified its import restrictions on environmental and health grounds. During the course of the proceedings, environmental groups submitted amicus curiae briefs to the Panel pertaining as to why the import restrictions were necessary. It was the subject of heavy debate because it involved a clash between rules that promote open trade and those to promote environmental protection. The case is also notable for being the first in which a developed country challenged an ostensibly environmental measure taken by a developing one. Brazil maintained that its measures were justified under GATT Article XX, which spells out exceptions in which members may deviate from their WTO obligations. The EC countered that such an argument was not justifiable, not only because it imported retreaded tyres from elsewhere in Mercosur, but that it also continued to import used tyres to convert them into retreaded tyres domestically. On 12 June 2007, the
Panel's report was circulated to Members. The Panel concluded that Brazil's import prohibition on retreaded tyres was inconsistent with Article XI:1 of the GATT 1994 because it prohibited the issuance of import licences for retreaded tyres. It further ruled that it was not justified under Article XX because Brazil applied the measure in a manner that constituted a means of unjustifiable discrimination and a disguised restriction to international trade within the meaning of the chapeau of the same article.

\section{CONCLUSION}

Both trade and environment are crucial for the well being of human society. What is most important is to strike a proper balance between free trade and environmental protection. There are a large number of multilateral environmental agreements. These MEAs usually incorporate environmental norms that may result in clashes with trade norms of the WTO. Reconciliation can only be possible with good faith negotiations under the Doha Development Agenda with renewed vigour and full commitments from both trade and environment advocates. Since both the WTO Agreements and MEAs are international treaties, they are subject to the interpretative rules of the law treaties. Should a dispute involving a clash between the WTO rules and MEAs arise, a crucial question that needs to be tackled first is the selection of the forum whether the appropriate forum is the dispute settlement body of the WTO or that of the relevant MEA. In the event of any future conflict between the WTO rules and MEAs, trade advocates cannot simply argue that the WTO Agreements take priority and thus prevail over any other conflicting international treaties because the environmental side has the ability to argue the same. The best way to avoid such a situation is to include a 'conflict clause' or at least to contain cross references in both types of Agreements. When a dispute arises between WTO members, stemming from their obligations under a MEA, the CTE prefers that the parties use the environmental treaty's dispute resolution process, rather than filing a complaint with the WTO dispute resolution panel. However, this does not address the problem of a dispute arising between WTO members, when one member is a party to the MEA from which the dispute arises and the other member is not a party to the MEA. This scenario has not yet materialized, but it has sparked heated debate and raised many concerns regarding the supremacy of GATT versus MEAs in the context of international law. Fortunately, the debate over supremacy appears to be becoming a moot point due to the proliferation of State 
membership in MEAs, which on average outnumbers that of WTO membership. The party/non-party debate continues to be an issue with the United States, which has backed out of the Kyoto Protocol and is also a nonparty to several other MEAs.

\section{REFERENCES}

1. Charnovitz, S., 1994. Free trade, fair trade, green trade: Defogging the debate. Cornell Int. Law J., 27: 459-461.

2. Bhagwati, J., 1993. Trade and Environment: The False Conflict. In: Trade and Environment: Law Economic and Policy, Zaelke, D., P. Orbuch and R.F. Housman (Eds.). Island Press, ISBNL 1559632682, pp: 159.

3. Shaffer, G.C., 2001. The world trade organization under challenge: Democracy and the law and politics of the WTO's treatment of environmental matter. Harvard Environ. Law. Rev., 25: 1-17.

4. Matsushita, M., T.J. Schoenbaum and P.C. Mavroidis, 2003. The World Trade Organization: Law, Practice and Policy. Oxford University Press, USA., ISBN: 10: 0198764723, pp: 776.

5. Jackson, J.H., W.J. Davey and A.O. Sykes, 2001. Legal Problems of International Economic Relations. 4th Edn., Thomson West Group Publishing, ISBN: 10: 0314246606, pp: 1245.

6. World Trade Organization, (WTO), 2001. Trading into the future: WTO the World Trade Organization. http://www.wto.org/english/res_e/doload_e/tif.pdf

7. Hoekman, B.M. and M.M. Kostecki, 2001. The Political Economy of World Trading System: WTO and Beyond. 2nd Edn., Oxford University Press, USA., ISBN: 10: 0198294344, pp: 576.
8. McCallion, K.F. and H.R. Sharma, 2000. Environmental justice without borders: The need for an international court of the environment to protect fundamental environmental rights. J. Int. Law Econ., 32: 351-359.

9. World Trade Organization, (WTO), 1995. Preamble' to the agreement establishing the world trade organization.

http://www.wto.org/english/docs_e/legal_e/04wto.pdf

10. World Trade Organization, (WTO), 1995. Environmental disputes in GATT/WTO. http://www.wto.org/english/tratop_E/envir_e/edis0 0_e.htm

11. World Trade Organization, (WTO), 2009. The "Tuna-Dolphin" case was brought by Mexico against the United States under the old GATT dispute settlement procedure. 